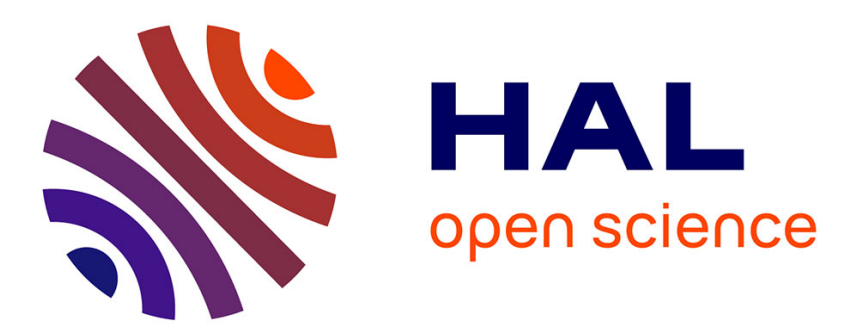

\title{
Modeling of the thermal and mechanical properties of clay ceramics incorporating organic additives
}

Pierre-Marie Nigay, Rababe Sani, Thierry Cutard, Ange Nzihou

\section{To cite this version:}

Pierre-Marie Nigay, Rababe Sani, Thierry Cutard, Ange Nzihou. Modeling of the thermal and mechanical properties of clay ceramics incorporating organic additives. Materials Science and Engineering: A, 2017, 708, p.375-382. 10.1016/j.msea.2017.09.131 . hal-01617979

\section{HAL Id: hal-01617979 \\ https://hal.science/hal-01617979}

Submitted on 6 Nov 2019

HAL is a multi-disciplinary open access archive for the deposit and dissemination of scientific research documents, whether they are published or not. The documents may come from teaching and research institutions in France or abroad, or from public or private research centers.
L'archive ouverte pluridisciplinaire $\mathbf{H A L}$, est destinée au dépôt et à la diffusion de documents scientifiques de niveau recherche, publiés ou non, émanant des établissements d'enseignement et de recherche français ou étrangers, des laboratoires publics ou privés. 


\title{
Modeling of the thermal and mechanical properties of clay ceramics incorporating organic additives
}

\author{
P.M. Nigay ${ }^{\mathrm{a}, \mathrm{b}, *}$, R. Sani ${ }^{\mathrm{a}}$, T. Cutard $^{\mathrm{b}}$, A. Nzihou $^{\mathrm{a}}$ \\ ${ }^{a}$ Centre RAPSODEE, Ecole des Mines d'Albi, Campus Jarlard, Route de Teillet, 81013 Albi Cedex 09, France \\ b Institut Clément Ader, Ecole des Mines d'Albi, Campus Jarlard, Route de Teillet, 81013 Albi Cedex 09, France
}

\begin{tabular}{|c|c|}
\hline & A B S T R A C T \\
\hline $\begin{array}{l}\text { Keywords: } \\
\text { Clay ceramic } \\
\text { Clay bricks } \\
\text { Organic additives } \\
\text { Porosity } \\
\text { Thermal conductivity } \\
\text { Mechanical strength }\end{array}$ & $\begin{array}{l}\text { This paper presents the results of a combined experimental and theoretical study on a clay ceramic used for } \\
\text { building applications. The thermal and mechanical properties of the clay ceramic were improved by addition of } \\
\text { organic additives. The organic additives consisted of Olive Stone Flour (OSF), with round-shape particles of } \\
55 \mu \mathrm{m} \text {, and Wheat Straw (WS), with } 877 \mu \mathrm{m} \text { particles in the form of fibers. It was found that the combustion of } \\
\text { OSF and WS resulted in a porosity formation during the firing process. The morphology of these pores corre- } \\
\text { sponded to that of the organic additives. Therefore, the addition of small OSF particles decreased the median } \\
\text { pore size of the clay ceramic. It improved the mechanical strength of the clay ceramic by } 12 \% \text { for an } 8 \mathrm{wt} \% \\
\text { addition of OSF. On the other hand, the WS fibers increased the clay ceramic anisotropy. This resulted in a } 41 \% \\
\text { improvement of the thermal conductivity using an } 8 \mathrm{wt} \% \text { addition of WS. Finally, a model was developed from } \\
\text { these experimental results to predict the thermal conductivity and the mechanical strength of the clay ceramic } \\
\text { with other organic additives. They were predicted from the parameters of the organic additives (i.e., true } \\
\text { density, swelling degree, particle size distribution, particle shape factor). The predictions indicated that the } \\
\text { thermal conductivity is improved by } 50 \% \text { with a } 25 \% \text { improvement of the mechanical strength using small } \\
\text { organic fibers, which is a step forward in the development of fired clay bricks that can be used for both insulation } \\
\text { and structure purposes in building applications. }\end{array}$ \\
\hline
\end{tabular}

\section{Introduction}

In the last decades, fired clay bricks were regarded as a potential media to dispose of waste materials. A wide range of industrial and urban wastes were incorporated into the bricks to deal with the growing amount of wastes $[1,2]$. But in a context of sustainability, the waste materials were gradually limited to the organic type of wastes. In fact, the organic wastes were incorporated into the bricks to release some heat in the tunnel kilns during the firing process [3]. This contributed to the reduction of fossil fuel consumptions and greenhouse gases emissions in the clay bricks industry $[4,5]$.

Progressively, the organic wastes have also been used in fired clay bricks as pore-forming agents [6-8]. The combustion of the organic wastes in the bricks induced a porosity formation during the firing process $[9,10]$. Hence, the low thermal conductivity of air in the newlyformed pores resulted in an important improvement of the thermal properties after firing of the clay bricks [11-13]. This improvement of the thermal properties was of great importance since it contributed to meet the challenge of reducing energy consumption in buildings [14].
However, the improvement of the thermal properties was associated with a significant decrease of the mechanical properties $[15,16]$. The mechanical properties of the bricks were decreased by the newlyformed pores acting as defects in the microstructure $[17,18]$. Hence, the use of organic wastes came to an issue since the building materials such as fired clay bricks require both insulation and resistance performances.

Recently, some studies have shown that the thermal and mechanical properties of fired clay bricks can be improved at the same time using organic additives with a small particle size [19]. This use of organic additives is a significant step forward in regards to the earliest objective of waste disposal. However, it restrains the range of waste materials that can be incorporated into the bricks. The literature shows that the improvement of both thermal and mechanical properties of fired clay bricks remains limited to the incorporation of specific wastes. Hence, the objective of this study is to develop a model to predict the thermal and mechanical properties of the fired clay bricks with organic additives. The properties will be predicted from intrinsic parameters of the organic additives. In this way, the predictions of the model will provide an insight into which organic wastes can be used to improve

\footnotetext{
* Corresponding author.

E-mail addresses: pierre-marie.nigay@mines-albi.fr (P.M. Nigay), rababe.sani@mines-albi.fr (R. Sani), thierry.cutard@mines-albi.fr (T. Cutard), ange.nzihou@mines-albi.fr (A. Nzihou).
} 
Table 1

Elemental composition of the clay with the concentrations in silicon, aluminum, calcium, iron, potassium and magnesium oxides.

\begin{tabular}{lllllll}
\hline \multirow{2}{*}{ Sample } & \multicolumn{6}{l}{ Concentration (wt\%) } \\
\cline { 2 - 7 } & $\mathrm{SiO}_{2}$ & $\mathrm{Al}_{2} \mathrm{O}_{3}$ & $\mathrm{CaO}$ & $\mathrm{Fe}_{2} \mathrm{O}_{3}$ & $\mathrm{~K}_{2} \mathrm{O}$ & $\mathrm{MgO}$ \\
\hline Clay & 44.8 & 16.8 & 9.4 & 9.9 & 3.8 & 1.9 \\
\hline
\end{tabular}

the thermal and the mechanical properties. This should widen the range of organic wastes that can be incorporated as pore-forming agents and energy carriers in fired clay bricks.

\section{Materials and experimental methods}

\subsection{Raw materials}

The clay that was used in this study was extracted from a clay quarry in the Toulouse Area (France). The clay was ground into particles of approximately $3 \mathrm{~mm}$ with a rolling mill (LA 1527, Vicentini). The elemental composition of the clay was measured using an ICP-AES instrument (Jobin Yvon Ultima 2). The clay was dissolved in a mixture of hydrofluoric and perchloric acid via heating at a temperature of $80{ }^{\circ} \mathrm{C}$ for $30 \mathrm{~min}$ [20]. The solution was diluted 10 times in purified water before analysis. The results of the ICP-AES analysis are given in Table 1. They show a predominance of silicon and aluminum oxides with smaller concentrations of calcium, iron and potassium oxides.

The organic additives that were used in this study consisted of Olive Stone Flour (OSF) and Wheat Straw (WS). The OSF additive obtained from BARDON Company was used in the given form. The WS additive obtained from ARTERRIS Cooperative was ground at $1 \mathrm{~mm}$ with a knife mill (Pulverisette 15, Fritsch). The composition of the organic additives was measured using organic elemental analysis (Flash 2000, Thermo Fischer Scientific). The results of the organic elemental analysis are summarized in Table 2. They show that OSF additive is composed of carbon, oxygen, hydrogen and nitrogen for more than $98 \mathrm{wt} \%$. WS additive is composed of the same elements than OSF additive with smaller concentrations in carbon, oxygen and hydrogen. This means that WS additive has a smaller organic fraction of approximately $87 \mathrm{wt}$ $\%$.

The true density of the organic additives was measured using helium pycnometry analysis (Accupyc 1330, Micromeritics). The results of the true density analyses are summarized in Table 3. They show that OSF additive has a relatively high density compared to that of WS additive.

The swelling ratio of the organic additives was estimated from a water absorption technique [21]. In fact, the organic additives were dried at $105^{\circ} \mathrm{C}$ for $24 \mathrm{~h}$ in an electrical hoven (Memmert). The mass and the volume of the samples were measured using a balance and a measuring cylinder. Subsequently, the samples were immersed in water for $48 \mathrm{~h}$. The samples were then removed from the water and subjected to a final measure of mass. The swelling ratio of the organic additives was calculated from Eq. (1), where $S_{r}$ is the swelling ratio, $m_{s}$ is the mass after the swelling operation, $\mathrm{m}_{\mathrm{d}}$ is the mass after the drying operation, $V_{d}$ is the volume after the drying operation, and $\rho_{w}$ is the

\section{Table 2}

Elemental composition of the organic additives with the concentrations in carbon, hydrogen, oxygen, nitrogen and sulfur elements.

\begin{tabular}{|c|c|c|c|c|c|}
\hline \multirow[t]{2}{*}{ Sample } & \multicolumn{5}{|c|}{ Concentration (wt $\%$ ) } \\
\hline & $\mathrm{C}$ & $\mathrm{H}$ & $\mathrm{O}$ & $\mathrm{N}$ & S \\
\hline OSF & 49.8 & 6.0 & 42.0 & 0.4 & 0.0 \\
\hline WS & 43.1 & 5.5 & 28.5 & 0.7 & 0.0 \\
\hline
\end{tabular}

Table 3

True density, swelling degree, particle size, and particle shape factor of the organic additives.

\begin{tabular}{lllll}
\hline Sample & Density $\left(\mathrm{g} \mathrm{cm}^{-3}\right)$ & Swelling degree & Particle size $(\mu \mathrm{m})$ & Shape factor \\
\hline OSF & 1.45 & 2.03 & 55 & 0.65 \\
WS & 1.39 & 3.55 & 877 & 0.15 \\
\hline
\end{tabular}

density of water.

$\mathrm{S}_{\mathrm{r}}=\frac{\left(\mathrm{m}_{\mathrm{s}}-\mathrm{m}_{\mathrm{d}}\right) / \rho_{\mathrm{w}}}{\mathrm{V}_{\mathrm{d}}}$

Finally, the swelling ratio of the samples was used to determine the swelling degree of the organic additives. The swelling degree of the organic additives was calculated from Eq. (2), where $S_{d}$ is the swelling degree and $S_{r}$ is the swelling ratio. It is important to note that the swelling degree of the organic additives is highly related to the true density. In fact, the organic additives with a low density absorb an extensive amount of water due to a greater porosity. Hence, WS additive has an important swelling degree of 3.55 compared to that of OSF additive of 2.03 .

$\mathrm{S}_{\mathrm{d}}=\frac{100+\mathrm{S}_{\mathrm{r}}}{100}$

The particle size distribution of the organic additives was measured using laser granulometry analysis (Mastersizer 3000, Malvern). The results of the analyses are summarized in Table 3. They show that OSF additive has a small average particle size of $55 \mu \mathrm{m}$ compared to that of WS additive of $877 \mu \mathrm{m}$. The organic additives were observed by scanning electron microscopy (SEM) using a Philips XL30 apparatus. The SEM micrographs of the organic additives are presented in Fig. 1. They show that OSF is composed of round-shape particles with a diameter of around $60 \mu \mathrm{m}$. On the other hand, the WS additive is composed of fibers with dimensions up to $900 \mu \mathrm{m}$. The particle shape factor of the organic additives was then determined from the SEM micrographs. It was calculated as the ratio of the breadth to the length of the particles. Finally, the particles of OSF have an important shape factor of 0.65 compared to that of WS of 0.15 .

\subsection{Processing of the clay ceramic}

The clay ceramic that was used in this study consisted of different mixtures of clay with organic additives and water. The mixtures were prepared in a bowl by mixing $10 \mathrm{~kg}$ of clay with $4 \mathrm{wt} \%$ and $8 \mathrm{wt} \%$ of organic additives (OSF or WS). The mixtures were kneaded for $5 \mathrm{~min}$ with a gradual addition of water. In fact, water was added to the mixtures until an 8 bar pressure of extrusion was obtained. The mixtures were then extruded in the form of blocks with dimensions of 180 $\times 80 \times 18 \mathrm{~mm}^{3}$ for a water content of $17 \mathrm{wt} \%$. The blocks were dried at $25{ }^{\circ} \mathrm{C}, 65{ }^{\circ} \mathrm{C}$ and $105{ }^{\circ} \mathrm{C}$ for $24 \mathrm{~h}$ in an electrical oven (Memmert). Following this operation, the different samples of the study were prepared from the blocks using a tabletop saw (Skil). The thickness of the samples was also adjusted with P80, P120, P180 and P280 SiC abrasive papers (Buehler). Finally, the samples were subjected to firing at $950{ }^{\circ} \mathrm{C}$ in an electrical furnace (Nabertherm Controler C320).

\subsection{Characterization of the microstructure}

The porosity of the clay ceramic was measured using a water absorption technique [22]. The measurements were performed with samples of $30 \times 30 \times 5 \mathrm{~mm}^{3}$. In fact, the samples were introduced in a vacuum chamber and maintained under a residual pressure of $30 \mathrm{kPa}$ for $4 \mathrm{~h}$. Some water was then introduced in the vacuum chamber up to partial immersion of the samples. The samples remained partially immersed under the same residual pressure of $30 \mathrm{kPa}$ for $2 \mathrm{~h}$. 

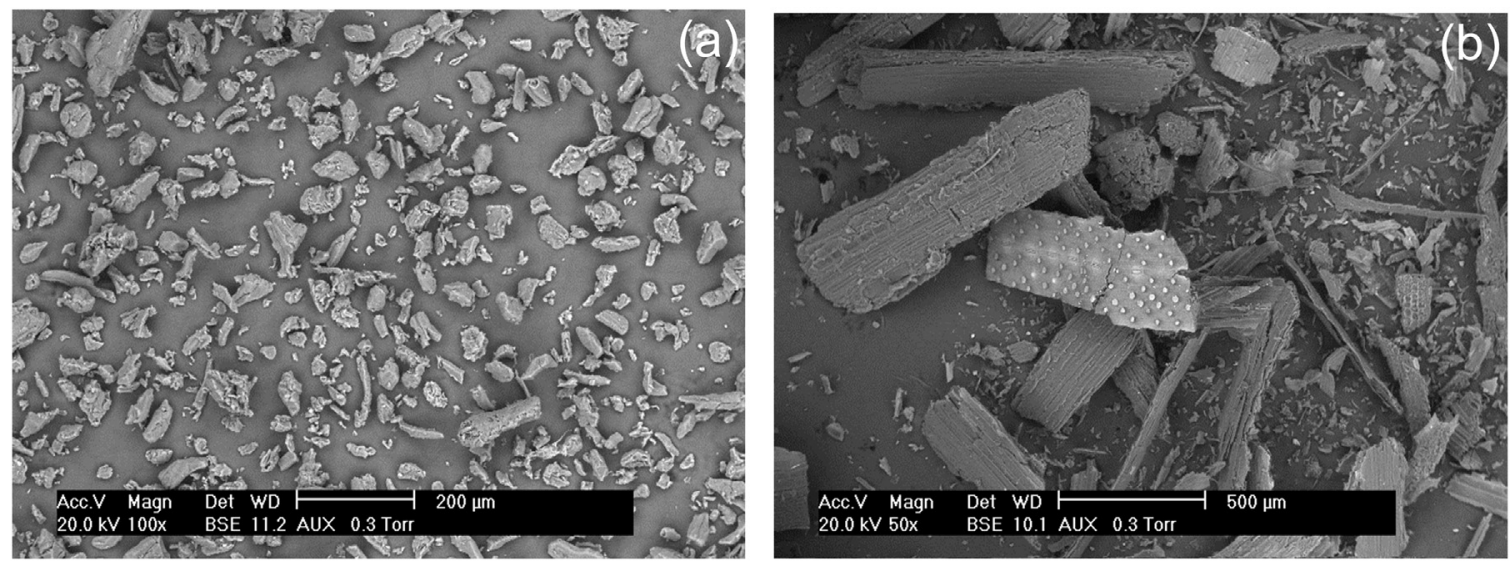

Fig. 1. SEM micrographs of the OSF additive (a) and of the WS additive (b).

Subsequently, some more water was introduced in the vacuum chamber to get the samples fully immersed. The full immersion of the samples was maintained for $24 \mathrm{~h}$. The atmospheric pressure was finally restored in the vacuum chamber. The samples remained immersed at atmospheric pressure for $24 \mathrm{~h}$. Following this operation, the mass of the samples was measured under three different conditions. It was measured under water by hydrostatic weighing, under air after wet wiping, and under air after drying at $105^{\circ} \mathrm{C}$. In this way, the porosity of the clay ceramic could be calculated from Eq. (3), where $\varepsilon$ is the percentage of porosity, $\mathrm{m}_{\mathrm{h}}$ is the hydrostatic mass, $\mathrm{m}_{\mathrm{w}}$ is the wet mass, and $\mathrm{m}_{\mathrm{d}}$ is the dry mass.

$\varepsilon=\frac{m_{w}-m_{d}}{m_{w}-m_{h}}$

The pore size of the clay ceramic was estimated by X-ray tomography analysis using the Synchrotron facility at ESRF Grenoble. The samples were analyzed in the form of $200 \mathrm{mg}$ cylinders. In fact, the cross-section micrographs of the samples were used to build a 3D representation of the porosity via imaging software. The pore size of the clay ceramic was then obtained from the 3D representation of the porosity. It is important to note that the 3D representation of the porosity shows the porosity of the clay ceramic in a light grey color.

The anisotropy of the clay ceramic was estimated from unidirectional measurements of the thermal diffusivity, using a Profilux Plus 800 (Multiblitz) instrument. In fact, the thermal diffusivity was measured parallel and perpendicular to the extrusion plane direction with samples of $30 \times 30 \times 5 \mathrm{~mm}^{3}$ that were prepared from the respective cuts in the large extruded blocks. The estimates of the anisotropy were then obtained by dividing the parallel to the extrusion plane direction values by the perpendicular to the extrusion plane values.

\subsection{Determination of the thermal properties}

The thermal properties of the clay ceramic (multidirectional) were measured using a transitory plane source method (TPS 2500, Hot Disk AB) [23]. The analyses were performed at room temperature with duplicate samples of $30 \times 30 \times 5 \mathrm{~mm}^{3}$. The thermal conductivity was then estimated from the thermal response of the samples with the dimension and the power of the probe. This was done using algorithms of the Thermal Constant Analyzer software.

\subsection{Determination of the mechanical properties}

The mechanical properties of the clay ceramic were measured by three-point bending. The measurements were performed in an Instron $5800 \mathrm{R}$ machine with a loading span of $40 \mathrm{~mm}$ and a load cell of $500 \mathrm{~N}$. The specimens with dimensions of $60 \times 30 \times 5 \mathrm{~mm}^{3}$ were loaded at a constant displacement rate of $1 \mathrm{~mm} / \mathrm{min}$ until the onset of the fracture. $\sigma_{\mathrm{f}}=\frac{3 \mathrm{~F}_{\mathrm{Max}} \mathrm{L}}{2 \mathrm{BH}^{2}}$

The mechanical strength of the clay ceramic was estimated from Eq. (4), where $\sigma_{f}$ is the mechanical strength, $F_{\text {Max }}$ is the maximum force, $L$ is the loading span, $\mathrm{B}$ is the breadth of the specimens and $\mathrm{H}$ is the height of the specimens [24]. Note that the results of the mechanical strength correspond to the average value obtained from the results of 10 tests.

\section{Modeling}

\subsection{Porosity}

The prediction of the percentage of porosity was based on the additive and conservative behavior of the porosity [25]. In fact, the porosity generated by combustion of the organic additives did not eliminate the porosity of the clay ceramic. The porosity generated by combustion of the organic additives at temperatures between $250{ }^{\circ} \mathrm{C}$ and $500{ }^{\circ} \mathrm{C}$ was also conserved during the sintering. The percentage of porosity after firing of the clay ceramic with organic additives was then regarded as equal to the sum of the percentages of porosity. It was obtained from Eq. (5), where $\varepsilon_{\text {Clay ceramic }}$ is the percentage of porosity of the clay ceramic with no organic additives and $\varepsilon_{\text {Organic additives }}$ is the percentage of porosity generated by combustion of the organic additives.

$\varepsilon=\varepsilon_{\text {Clay ceramic }}+\varepsilon_{\text {Organic additives }}$

The percentage of porosity of the clay ceramic with no organic additives was measured as described earlier in Section 2.3. It was equal to $30 \mathrm{vol} \%$ after firing of the clay ceramic at $950{ }^{\circ} \mathrm{C}$. On the other hand, the porosity generated by combustion of the organic additives corresponded to the maximal volume of organic additives in the clay ceramic [26]. It was then obtained by transposition of the mass percentage of addition into a volume percentage of addition using the density and the swelling degree of the organic additives (Eq. (6)). It is important to note that the true density was used in this case over the bulk density since the organic additives were compressed in the clay matrix. This gives:

$\varepsilon_{\text {Organic additives }}=\frac{\%_{\text {Organic additives }}}{\rho_{\text {Organic additives }}} \times S_{\mathrm{dOrganic} \text { additives }}$

Where \%organic additives is the mass percentage of addition, $\rho_{\text {Organic ad- }}$ ditives is the true density, and $S_{d}$ Organic additives is the swelling degree of the organic additives.

\subsection{Median pore size}

The median pore size of the clay ceramic was predicted using the proportion and the size of each type of pores. The predictions were 
made from Eq. (7), where $\varepsilon_{\text {Clay ceramic }}$ is the percentage of porosity of the clay ceramic with no organic additives, $\varepsilon_{\text {Organic additives }}$ is the percentage of porosity generated by combustion of the organic additives, $\Phi_{\text {Clay }}$ ceramic is the median pore size of the clay ceramic with no organic additives, and $\Phi_{\text {Organic additives }}$ is the median size of the pores generated by combustion of the organic additives.

$\phi=\left(\frac{\varepsilon_{\text {Clay ceramic }} \times \phi_{\text {Clay ceramic }}}{\varepsilon_{\text {Clay ceramic }}+\varepsilon_{\text {Organic additives }}}\right)+\left(\frac{\varepsilon_{\text {Organic additives }} \times \phi_{\text {Organic additives }}}{\varepsilon_{\text {Clay ceramic }}+\varepsilon_{\text {Organic additives }}}\right)$

The median pore size of the clay ceramic with no organic additives was determined from the X-ray tomography analysis described in Section 2.3. It was equal to $150 \mu \mathrm{m}$ after firing at a temperature of $950{ }^{\circ} \mathrm{C}$ [27]. On the other hand, the median size of the pores generated by the combustion of organic additives was taken as the average size of the particles of organic additives. This could be done since the size of the newly-formed pores was not modified during the firing process of the clay ceramic. Furthermore, the percentages of porosity were obtained from the previous results of the modeling (Section 3.1).

\subsection{Anisotropy}

Similarly, the anisotropy was predicted using the proportion and the shape of each type of pores. This could be done for such a fired clay ceramic since the contribution of the solid skeleton (i.e., platelet structure) to the anisotropy is removed after firing at high temperature [28]. Hence, the predictions were made from Eq. (8), where $\varepsilon_{\text {Clay ceramic }}$ is the percentage of porosity of the clay ceramic with no organic additives, $\varepsilon_{\text {Organic additives }}$ is the percentage of porosity generated by combustion of the organic additives, $\gamma_{\text {Clay ceramic }}$ is the anisotropy of the clay ceramic with no organic additives, and $\gamma_{\text {Organic additives }}$ is the median anisotropy of the pores generated by combustion of the organic additives.

$\gamma=\left(\frac{\varepsilon_{\text {Clay ceramic }} \times \gamma_{\text {Clay ceramic }}}{\varepsilon_{\text {Clay ceramic }}+\varepsilon_{\text {Organic additives }}}\right)+\left(\frac{\varepsilon_{\text {Organic additives }} \times \gamma_{\text {Organic additives }}}{\varepsilon_{\text {Clay ceramic }}+\varepsilon_{\text {Organic additives }}}\right)$

The anisotropy of the clay ceramic with no organic additives was measured as described in Section 2.3. It was equal to 1.4 after firing of the clay ceramic at $950{ }^{\circ} \mathrm{C}$. Furthermore, the anisotropy of the newlyformed pores was calculated from Eq. (9) with the particle shape factor of the organic additives. This gives:

$\gamma_{\text {Organic additives }}=\frac{1}{c \times \mathrm{f}_{\text {Organic additives }}}$

Where $f_{\text {Organic additives }}$ is the average shape factor of the particles of organic additives and $\mathrm{c}$ is a constant equal to 2.5. It is important to note that the percentages of porosity were all obtained from the previous results of the modeling (Section 3.1).

\subsection{Thermal properties}

The thermal properties of the clay ceramic were predicted using a parallel model (Eq. (10)). The model predicts the thermal conductivity of the clay ceramic $(\lambda)$ from the thermal conductivity of the solid skeleton $\left(\lambda_{\text {Solid }}\right)$, the thermal conductivity of air $\left(\lambda_{\text {Air }}\right)$, and the effective volume of porosity ( $\left.\varepsilon_{\mathrm{eff}}\right)[29]$.

$\lambda=\left(1-\varepsilon_{\text {eff }}\right) \lambda_{\text {Solid }}+\left(\varepsilon_{\text {eff }} \times \lambda_{\text {Air }}\right)$

The thermal conductivity of the solid skeleton was regarded as equal to $1.60 \mathrm{~W} /(\mathrm{m} . \mathrm{K})$. This value was determined from the thermal conductivity of the clay ceramic with no organic additives. Furthermore, the thermal conductivity of air was retrieved from the literature as $0.026 \mathrm{~W} /(\mathrm{m} . \mathrm{K})$ [30]. The percentage of porosity that is found in the conventional model was also replaced by the effective volume of porosity. The effective volume of porosity was obtained from Eq. (11), where $\varepsilon$ is the percentage of porosity and $\gamma$ is the anisotropy. It is important to note that the anisotropy replaces the empirical parameter that was used in the original study [31]. This empirical parameter was replaced by the anisotropy to adapt the impact of anisotropic pores to the parallel model which is made to represent the impact of isotropic pores. In this way, the great impact of the anisotropic pores on the thermal conductivity of the clay ceramic could be regarded as equivalent to the impact of a greater volume fraction of small pores using a single model.

$\varepsilon_{\text {eff }}=\frac{2^{\gamma}}{2^{\gamma}-1}\left(1-\frac{1}{(1+\varepsilon)^{\gamma}}\right)$

The percentage of porosity and the anisotropy of the clay ceramic were obtained from the results of the modeling described in Sections 3.1 and 3.3, respectively. This means that the model predicted the evolution of the thermal conductivity with the only parameters of the organic additives (i.e., true density, swelling degree and particle shape factor).

\subsection{Mechanical properties}

The mechanical properties of the clay ceramic were predicted using the damage model in Eq. (12) [32]. The damage model predicts the mechanical strength of the clay ceramic under a flexural loading $\left(\sigma_{\mathrm{f}}\right)$ from the damage of the clay ceramic (D) and the mechanical strength of the solid skeleton $\left(\sigma_{\text {Solid }}\right)[33]$.

$\sigma_{\mathrm{f}}=(1-\mathrm{D}) \sigma_{\text {Solid }}$

The mechanical strength of the solid skeleton was regarded as equal to $35.0 \mathrm{MPa}$. It was obtained from the mechanical strength of the clay ceramic with no organic additives. On the other hand, the damage of the clay ceramic was estimated from Eq. (13), where $\varepsilon$ is the percentage of porosity and $\Phi$ is the median pore size. It is important to note that this law corresponds to the equivalence of the law that was used for the modeling of the thermal conductivity. This law was preferred to the conventional laws for the modeling of the mechanical strength because of its two variables [34]. In fact, the impact of the small and large pores on the mechanical strength could be estimated using a single model. The impact of large pores was regarded as equivalent to that of a greater volume fraction of small pores [35].

$\mathrm{D}=\frac{2^{\phi}}{2^{\phi}-1}\left(1-\frac{1}{(1+\varepsilon)^{\phi}}\right)$

The percentage of porosity and the median pore size were obtained from the results of the modeling described earlier in Sections 3.1 and 3.2 , respectively. This means that the damage model predicted the evolution of the mechanical strength with the only parameters of the organic additives (i.e., density, swelling degree and particle size distribution).

\section{Results and discussion}

\subsection{Porosity of the clay ceramic}

The dependence of the porosity on the percentage of organic additives is presented in Fig. 2. The clay ceramic with no organic additives has a porosity of $30 \mathrm{vol} \%$ after firing at the temperature of $950{ }^{\circ} \mathrm{C}$ [36]. This value corresponds to the air retained in the clay ceramic during the extrusion process. It also corresponds to the porosity which is forming with the $\mathrm{H}_{2} \mathrm{O}$ and $\mathrm{CO}_{2}$ release from the mineralogical transformations, such as dehydroxylation and decarbonation, during the firing process.

The addition of organic additives results in a porosity increase of the clay ceramic after the firing process. However, the extent of the porosity increase depends on the density of the organic additives. The organic additives with a low density occupy a greater volume than organic additives with a high density. They are also subjected to a 


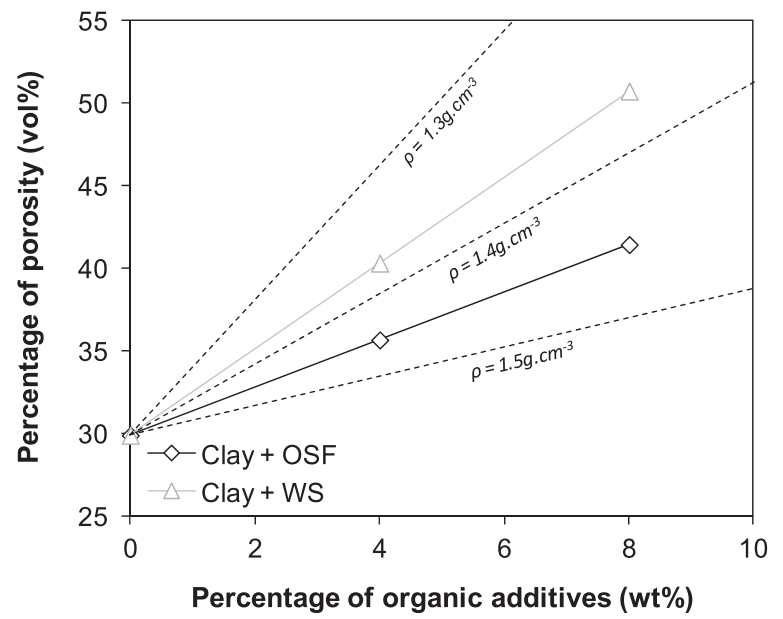

Fig. 2. Dependence of the percentage of porosity of the clay ceramic on the percentage of organic additives after firing at $950{ }^{\circ} \mathrm{C}$.

greater volume increase due to water swelling. Hence, the combustion of these organic additives releases a greater volume of porosity during the firing process. The $8 \mathrm{wt} \%$ addition of OSF induces a porosity increase of $12 \mathrm{vol} \%$. The porosity of the clay ceramic is then limited to $42 \mathrm{vol} \%$ for an $8 \mathrm{wt} \%$ addition of OSF. On the other hand, the $8 \mathrm{wt} \%$ addition of WS with a relatively low density leads to a porosity increase of $20 \mathrm{vol} \%$. The clay ceramic has then a high porosity of $50 \mathrm{vol} \%$ in case of an $8 \mathrm{wt} \%$ addition of WS.

The porosity of the clay ceramic with organic additives is relatively well predicted by Eqs. (5) and (6). They represent a linear increase of the porosity from that of the clay ceramic with no organic additives. The slope of the porosity increase also corresponds to the ratio of the swelling degree to the true density of the organic additives. This means that the porosity of the clay ceramic with other organic additives could be predicted using the only parameters of these (i.e., true density, swelling degree).

\subsection{Pore size of the clay ceramic}

The dependence of the median pore size on the percentage of organic additives is shown in Fig. 3. The clay ceramic with no organic additives has a median pore size of $150 \mu \mathrm{m}$ after firing at the temperature of $950{ }^{\circ} \mathrm{C}$. This value corresponds to the average size of the pores from the extrusion and firing processes. In fact, the extrusion induces a compression of the clay in a form of sheets. The air remaining

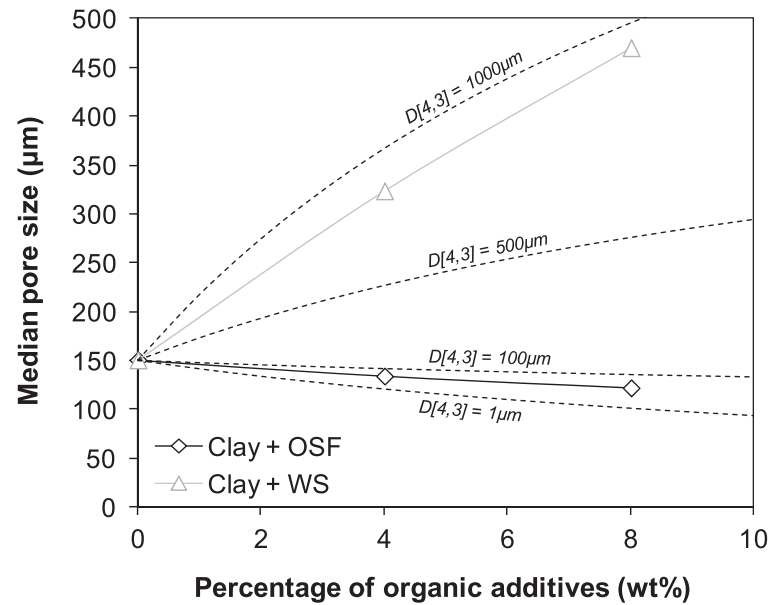

Fig. 3. Dependence of median pore size of the clay ceramic on the percentage of organic additives after firing at $950{ }^{\circ} \mathrm{C}$.
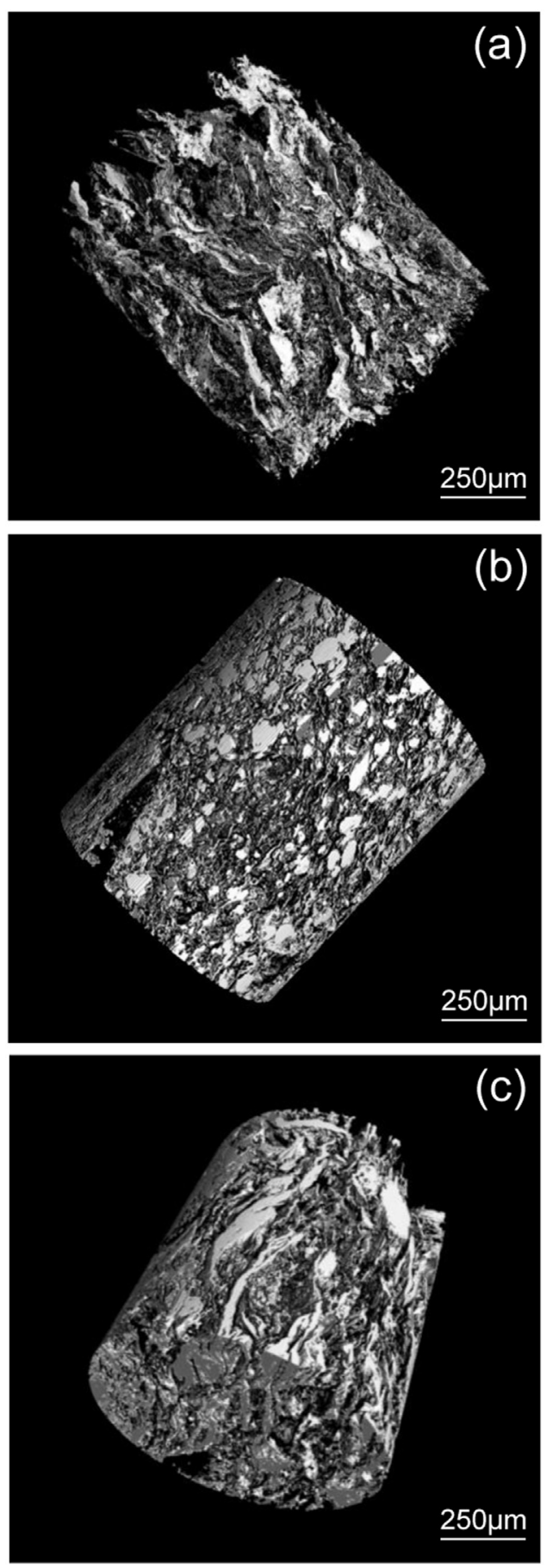

Fig. 4. 3D representation of the porosity obtained by X-ray tomography analysis of the clay ceramic (a) and of the clay ceramic with an $8 \mathrm{wt} \%$ addition of OSF (b) and WS (c) after firing at $950{ }^{\circ} \mathrm{C}$.

in the clay ceramic mixture is then compressed between the sheets of clay in a form of porosity sheets. Those large sheets of porosity can be observed via the 3D representation of the porosity obtained by X-ray tomography analysis in Fig. 4. They correspond to the largest defects of the microstructure after the firing process.

The organic additives with small particles induce a decrease of the median pore size of the clay ceramic. The small particles prevent the formation of large porosity sheets during the extrusion process. Moreover, the combustion of the small particles results in a formation of smaller pores than $150 \mu \mathrm{m}$ during the firing process. The size of those pores corresponds, as shown in Fig. 4, to the particle size of the organic 
additives. The median pore size of the clay ceramic is then decreased to $120 \mu \mathrm{m}$ in case of an $8 \mathrm{wt} \%$ addition of OSF with small $55 \mu \mathrm{m}$ particles. On the other hand, organic additives with large particles do not prevent the formation of large porosity sheets during the extrusion process. Those large particles also results in a formation of larger pores than $150 \mu \mathrm{m}$ during the firing process. Therefore, the median pore size of the clay ceramic is increased to $470 \mu \mathrm{m}$ in case of an $8 \mathrm{wt} \%$ addition of OSF with large $877 \mu \mathrm{m}$ particles.

Note that the median pore size of the clay ceramic with organic additives is relatively well predicted by Eq. (7). The predictions are made from the percentage of porosity and the particle size distribution of the organic additives. However, the porosity of the clay ceramic was yet predicted from the density and water swelling degree of the organic additives. This means that the median pore size could be predicted for an addition of other organic additives using the only parameters of these organic additives (i.e., true density, swelling degree, particle size distribution).

\subsection{Anisotropy of the clay ceramic}

The dependence of the anisotropy on the percentage of organic additives is presented in Fig. 5. The clay ceramic with no organic additives has an average anisotropy of 1.4 after firing at the temperature of $950^{\circ} \mathrm{C}$. This value represents the stacking of clay and porosity sheets of the extrusion process. In fact, the layered microstructure is conserved during the firing process of the clay ceramic.

The organic additives with an important particle shape factor result in a decrease of the anisotropy. In fact, the combustion of those roundshape particles induces a formation of round-shape pores, as shown in Fig. 4. The decrease of the anisotropy is then due to the isotropic behavior of the newly-formed pores. In case of an $8 \mathrm{wt} \%$ addition of OSF, with round-shape particles, the anisotropy of the clay ceramic is decreased to 1.1. However, the organic additives with a low particle shape factor are orientated with the clay during the extrusion process. The combustion of those fibers also leads to the formation of orientated pores during the firing process. Hence, the anisotropic behavior of the newly-formed pores results in an increase of the clay ceramic anisotropy. The anisotropy of the clay ceramic is increased up to 1.9 in case of an $8 \mathrm{wt} \%$ addition of WS fibers.

It is important to note that the anisotropy of the clay ceramic is relatively well predicted by Eq. (8). In fact, the predictions of the anisotropy are made from the porosity of the clay ceramic and the particle shape factor of the organic additives. The porosity of the clay ceramic was yet predicted from the density and the swelling degree of the organic additives. This means that the anisotropy of the clay ceramic

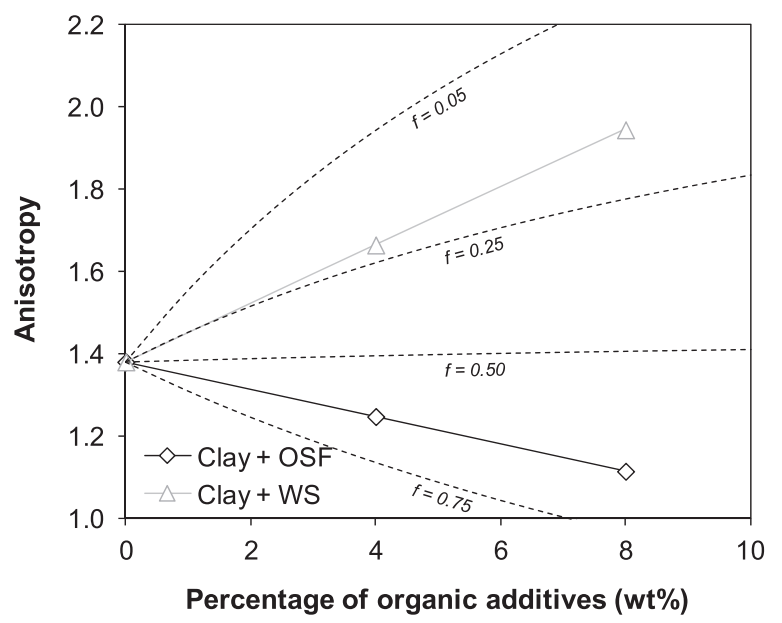

Fig. 5. Dependence of the anisotropy of the clay ceramic on the percentage of organic additives after firing at $950{ }^{\circ} \mathrm{C}$.

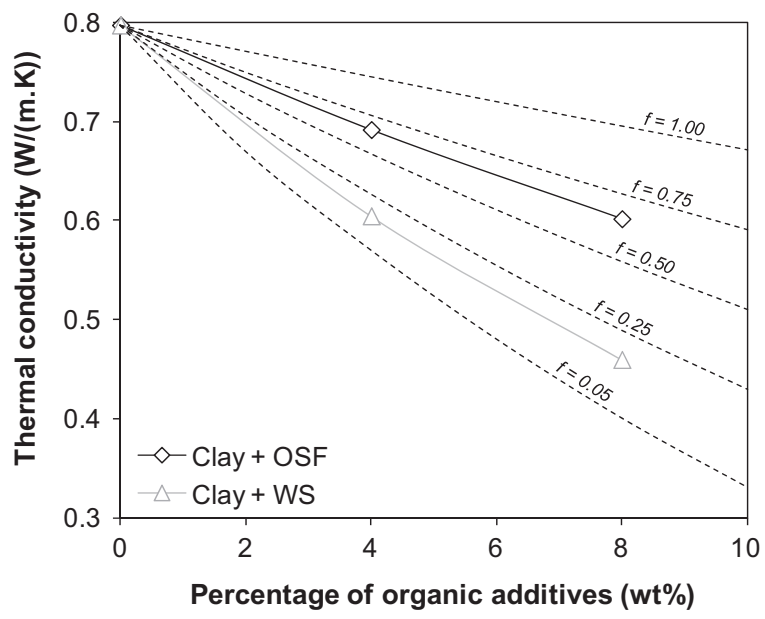

Fig. 6. Dependence of the thermal conductivity of the clay ceramic on the percentage of organic additives after firing at $950{ }^{\circ} \mathrm{C}$.

could be predicted in case of a different addition of organic additives using the only relevant parameters of those (i.e., true density, swelling degree, particle shape factor).

\subsection{Thermal properties of the clay ceramic}

The dependence of the thermal conductivity of the clay ceramic on the percentage of organic additives is presented in Fig. 6 . The clay ceramic with no organic additives has a thermal conductivity of $0.80 \mathrm{~W} /(\mathrm{m} . \mathrm{K})$ after firing at the temperature of $950{ }^{\circ} \mathrm{C}$. In fact, this value is a combination between the relatively high thermal conductivity of the solid skeleton and the relatively low thermal conductivity of air in the porosity. It is important to note that the impact of air is enhanced in that direction of the thermal gradient of the walls due to the anisotropic behavior of the porosity sheets.

The organic additives induce a significant decrease of the thermal conductivity of the clay ceramic. However, the decrease of the thermal conductivity depends on the particle shape factor of the organic additives. The organic additives with a relatively high particle shape factor such as OSF results in a formation of round-shape pores. The thermal conductivity is decreased by the low thermal conductivity of air in these pores. But, the decrease of the thermal conductivity remains limited to $23 \%$ in case of an $8 \mathrm{wt} \%$ addition of OSF due to a significant decrease in the anisotropy. The clay ceramic with an $8 \mathrm{wt} \%$ addition of OSF has then a thermal conductivity of $0.61 \mathrm{~W} /(\mathrm{m} . \mathrm{K}) \mathrm{K}$ after firing at the temperature of $950{ }^{\circ} \mathrm{C}$. On the other hand, the organic additives with a low particle shape factor such as WS results in a formation of orientated pores. This means that heat diffusion is highly limited through the stacking of clay and porosity sheets. Therefore, the $8 \mathrm{wt} \%$ addition of WS fibers induces an important decrease of the thermal conductivity of $41 \%$. The clay ceramic with an $8 \mathrm{wt} \%$ addition of WS fibers has then a thermal conductivity of $0.46 \mathrm{~W} /(\mathrm{m} . \mathrm{K}) \mathrm{K}$ after the firing process.

The predictions of the model (Eqs. (10) and (11)) are in agreement with the experimental results. This means that the thermal conductivity can be predicted from the percentage of porosity and the anisotropy of the clay ceramic. These estimates of the microstructure are obtained from the density, the swelling degree and the particle shape factor of the organic additives. Therefore, the thermal conductivity of the clay ceramic can be predicted for other organic additives using the same approach. These predictions provide information for a greater improvement of the thermal conductivity. In fact, the thermal conductivity of the clay ceramic could be improved up to $50 \%$ using an $8 \mathrm{wt} \%$ addition of organic fibers. 


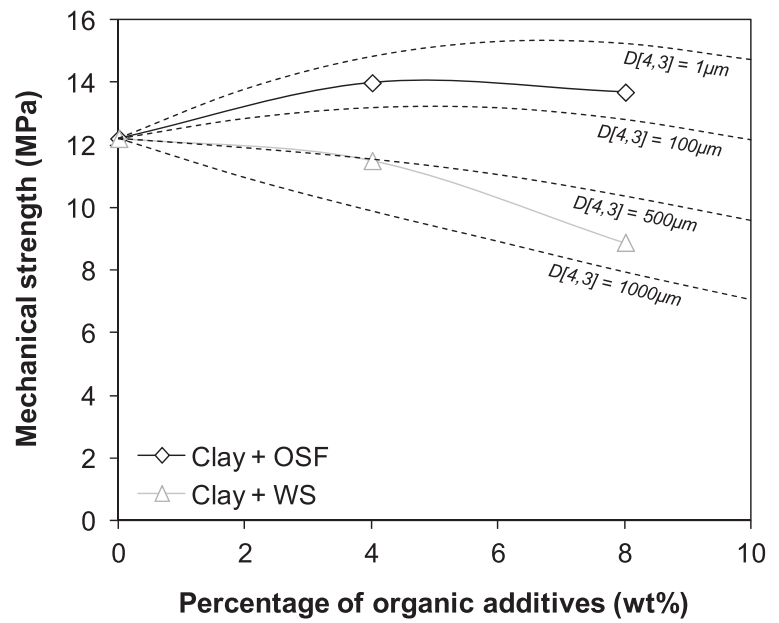

Fig. 7. Dependence of the mechanical strength of the clay ceramic on the percentage of organic additives after firing at $950{ }^{\circ} \mathrm{C}$.

\subsection{Mechanical properties of the clay ceramic}

The dependence of the mechanical strength of the clay ceramic on the percentage of organic additives is shown in Fig. 7. The clay ceramic with no organic additives has a mechanical strength of 12.2 MPa after firing at the temperature of $950{ }^{\circ} \mathrm{C}$. This value corresponds to a combination between the bonding of the clay particles and the presence of defects such as $150 \mu \mathrm{m}$ sheets of porosity [37].

The organic additives with a small particle size increase the mechanical strength of the clay ceramic. In fact, the increase of the mechanical strength is associated with the decrease of the median pore size. The small pores act as a minor source of fracture compared to the $150 \mu \mathrm{m}$ sheets of porosity. Nevertheless, the impact of the pore volume fraction exceeds that of the pore size for greater percentages of additions than $8 \mathrm{wt} \%$. The mechanical strength of the clay ceramic is then increased by $12 \%$ in case of an $8 \mathrm{wt} \%$ addition of OSF additive with small $55 \mu \mathrm{m}$ particles. The clay ceramic with an $8 \mathrm{wt} \%$ addition of OSF has a mechanical strength of $13.7 \mathrm{MPa}$ after firing at the temperature of $950{ }^{\circ} \mathrm{C}$. On the other hand, the organic additives with an important particle size induce a significant decrease of the mechanical strength. The decrease of the mechanical strength is due to the increase of the median pore size. In fact, the mechanical strength of the clay ceramic decreases by $27 \%$ for an $8 \mathrm{wt} \%$ addition of WS with large $877 \mu \mathrm{m}$ particles. The clay ceramic with an $8 \mathrm{wt} \%$ addition of WS has then a mechanical strength of $8.9 \mathrm{MPa}$ after the firing process.

The results of the modeling (Eqs. (12) and (13)) are consistent with the results of the measurements. Therefore, the percentage of porosity and the median pore size of the clay ceramic are relevant parameters to model the mechanical strength. This means that the mechanical strength of the clay ceramic can be predicted by the model in the case of other organic additives since the estimates of the percentage of porosity and of the median pore size are obtained from the only parameters of the organic additives (i.e., true density, swelling degree, particle size distribution). In fact, the predictions indicate that the mechanical strength of the clay ceramic could be improved up to $25 \%$ using an $8 \mathrm{wt}$ $\%$ addition of small organic particles.

\subsection{Implications}

The implications of this research are significant for the use of poreforming agents in fired clay bricks. The literature has shown that the addition of pore-forming agents in fired clay bricks improves the thermal properties. However, it results in a significant decrease of the mechanical properties. This is the reason why the use of fired clay bricks incorporating pore-forming agents is usually limited to thermal insulation purposes [38].

In this study, a predictive model was developed to optimize the thermal and mechanical properties of fired clay bricks incorporating pore-forming agents. The results of the modeling indicated that the thermal properties are improved by $50 \%$ with a $25 \%$ improvement of the mechanical properties using an $8 \mathrm{wt} \%$ addition of small organic fibers. This means that fired clay bricks incorporating pore-forming agents can be used for both insulation and structure purposes if the pore-forming agents have the appropriate morphology, in contrast with the observations from the literature [39].

Typically, the current results show that the thermal and mechanical properties of fired clay bricks can be controlled by the particle size distribution and the particle shape factor of the pore-forming agents. This means that the properties can be enhanced by the addition of a number of organic wastes using a preliminary grinding of these.

\section{Conclusions}

This paper presents the results of a combined experimental and theoretical study on the development of a model to predict the thermal and mechanical properties of clay ceramics incorporating organic additives. Salient conclusions arising from this study are summarized below.

1. The combustion of the organic additives induced a porosity formation during the firing process. The porosity formed by combustion of the organic additives was equivalent to the maximal volume of organic additives in the clay ceramic. It came in addition to the porosity of the clay ceramic with no organic additives. Hence, the porosity of the clay ceramic with organic additives was calculated as the sum of the percentages of porosity using the true density and the water swelling degree of the organic additives.

2. The morphology of the newly-formed pores corresponded to the morphology of the organic additives. The organic additives with small particles decreased the median pore size of the clay ceramic. On the other hand, the organic additives in the form of fibers increased the clay ceramic anisotropy. The median pore size and anisotropy were then predicted from the particle size distribution and the particle shape factor of the organic additives.

3. The greatest improvement of the thermal properties was obtained by addition of organic additives with a low particle shape factor as a result of the increase in the clay ceramic anisotropy. On the other hand, the organic additives with a small particle size induced an extensive improvement of the mechanical properties due to the decrease of the median pore size. The thermal and mechanical properties of the clay ceramic were then predicted from the percentage of porosity, the anisotropy and the median pore size.

4. Finally, the predictions of the thermal and mechanical properties of the clay ceramic could be made using the only parameters of the organic additives (i.e., true density, swelling degree, particle size distribution, particle shape factor). It indicated that the thermal properties of the clay ceramic are improved by $50 \%$ with a $25 \%$ improvement of the mechanical properties using small organic fibers. This is a step forward in the development of fired clay bricks that can be used for both insulation and structure purposes in building applications. Nevertheless, some modeling of the pore volume fraction as a function of the temperature could still be integrated into the model to give some insight into the thermal and mechanical properties of eco-friendly bricks obtained from a lowtemperature firing.

\section{Acknowledgements}

The authors would like to acknowledge the TERREAL Company for financial support and scientific contribution to this study. We also thank the staff of the ICA and RAPSODEE Research Centers at Ecole des 
Mines d'Albi for assistance with the research.

\section{Funding}

This work was supported by the Agence Nationale de la Recherche et de la Technologie (CIFRE $\mathrm{N}^{\circ} 2011 / 1193$ ).

\section{Conflict of interest}

The authors declare that they do not have any conflict of interest.

\section{References}

[1] M. Dondi, M. Marsigli, B. Fabbri, Recycling of industrial and urban wastes in brick production - a review, Tile \& Brick Int. 13 (1997) 218-225.

[2] M. Dondi, M. Marsigli, B. Fabbri, Recycling of industrial and urban wastes in brick production - a review (Part 2), Tile \& Brick Int. 13 (1997) 302-315.

[3] A. Zani, A. Tenaglia, A. Panigada, Re-use of papermaking sludge in brick production, Ziegelind. Int. 12 (1990) 682-690.

[4] A. Kohler, Use of industrial wastes with combustible components in the brick and tile industry, Ziegelind. Int. 9 (1988) 441-445.

[5] A. Mohajerani, A.A. Kadir, L. Larobina, A practical proposal for solving the world's cigarette butt problem: recycling in fired clay bricks, Waste Manage. 52 (2016) 228-244.

[6] C. Bories, M.E. Borredon, E. Vedrenne, G. Vilarem, Development of eco-friendly porous fired clay bricks using pore-forming agents: a review, J. Environ. Manage. 143 (2014) 186-196.

[7] S.N. Monteiro, C.M.F. Vieira, On the production of fired clay bricks from waste materials: a critical update, Constr. Build. Mater. 68 (2014) 599-610.

[8] P. Muñoz Velasco, M.P. Morales Ortíz, M.A. Mendívil Giró, L. Muñoz Velasco, Fired clay bricks manufactured by adding wastes as sustainable construction material - a review, Constr. Build. Mater. 63 (2014) 97-107.

[9] I. Demir, Effect of organic residues addition on the technological properties of clay bricks, Waste Manage 28 (2008) 622-627.

[10] M. Sutcu, S. Ozturk, E. Yalamac, O. Gencel, Effect of olive mill waste addition on the properties of porous fired clay bricks using Taguchi method, J. Environ. Manage. 181 (2016) 185-192.

[11] V. Bánhidi, L.A. Gömze, Improvement of insulation properties of conventional brick products, Mater. Sci. Forum 589 (2008) 1-6.

[12] D. Eliche-Quesada, S. Martínez-Martínez, L. Pérez-Villarejo, F.J. Iglesias-Godino, C. Martínez-García, F.A. Corpas-Iglesias, Valorization of biodiesel production residues in making porous clay brick, Fuel Process Technol. 103 (2012) 166-173.

[13] M.A. Mendívil, P. Muñoz, M.P. Morales, V. Letelier, M.C. Juárez, Grapevine shoots for improving thermal properties of structural fired clay bricks: new method of agricultural-waste valorization, J. Mater. Civ. Eng. 29 (2017) 04017074.

[14] A.A. Kadir, A. Mohajerani, Recycling cigarette butts in lightweight fired clay bricks, Constr. Mater. 164 (2011) 219-229.

[15] L. Pérez-Villarejo, D. Eliche-Quesada, F.J. Iglesias-Godino, C. Martínez-García, F.A. Corpas-Iglesias, Recycling of ash from biomass incinerator in clay matrix to produce ceramic bricks, J. Environ. Manage. 95 (2012) 349-354.

[16] C. Bories, L. Aouba, E. Vedrenne, G. Vilarem, Fired clay bricks using agricultural biomass wastes: Study and characterization, Constr. Build. Mater. 91 (2015) $158-163$.

[17] C.M.F. Vieira, P.M. Andrade, G.S. Maciel, F. Vernilli, S.N. Monteiro, Incorporation of fine steel sludge waste into red ceramic, Mater. Sci. Eng. A 427 (2006) 142-147.

[18] A. Ukwatta, A. Mohajerani, Effect of organic content in biosolids on the properties of fired-clay bricks incorporated with biosolids, J. Mater. Civ. Eng. 29 (2017) 04017047.

[19] L.V. Korah, P.M. Nigay, T. Cutard, A. Nzihou, S. Thomas, The impact of the particle shape of organic additives on the microstructure of a clay ceramic and its thermal and mechanical properties, Constr. Build. Mater. 125 (2016) 654-660.

[20] ASTM International, Standard practice for total digestion of sediment samples for chemical analysis of various metals, D4698-92 (2013).

[21] ASTM International, Standard test method for water absorption of plastics, D570D598 (2010).

[22] ASTM International, Standard test methods for apparent porosity, liquid absorption, apparent specific gravity, and bulk density of refractory shapes by vacuum pressure, C830-00 (2016).

[23] ASTM International, Standard test method for measurement of thermal effusivity of fabrics using a modified transient plane source (MTPS) instrument, D7984-16 (2016).

[24] ASTM International, Standard test methods for flexural properties of unreinforced and reinforced plastics and electrical insulating materials, D790-10 (2010).

[25] E. Gregorová, Z. Živcová, W. Pabst, Starch as a pore-forming agent and bodyforming agent in ceramic technology, Starch/Stärke 61 (9) (2009) 495-502.

[26] Z. Živcová, E. Gregorová, W. Pabst, Alumina ceramics prepared with new poreforming agents, Process Appl. Ceram. 2 (1) (2008) 1-8.

[27] S. Freyburg, Schwarz, Influence of the clay type on the pore structure of structural ceramics, J. Eur. Ceram. Soc. 27 (2007) 1727-1733.

[28] J. Bourret, N. Tessier-Doyen, R. Guinebretiere, E. Joussein, D.S. Smith, Anisotropy of thermal conductivity and elastic properties of extruded clay-based materials: evolution with thermal treatment, Appl. Clay Sci. 116-117 (2015) 150-157.

[29] R.C. Progelhof, J.L. Throne, R.R. Ruetsch, Methods for predicting the thermal conductivity of composite systems: a review, Polym. Eng. Sci. 16 (9) (1976) 615-625.

[30] D.S. Smith, A. Alzina, J. Bourret, B. Nait-Ali, F. Pennec, N. Tessier-Doyen, K. Otsu, H. Matsubara, P. Elser, U.T. Gonzenbach, Thermal conductivity of porous materials, J. Mater. Res. 28 (2013) 2260-2272.

[31] A. Sugarawa, Y. Yoshizawa, An investigation on the thermal conductivity of porous materials and its application to porous rock, Austr. J. Phys. 14 (1961) 469-480.

[32] J. Lemaitre, A continuous damage mechanics model for ductile fracture, J. Eng. Mater. Technol. 107 (1985) 83-89.

[33] J.W. Ju, Isotropic and anisotropic damage variables in continuum damage mechanics, J. Eng. Mech. 116 (12) (1990) 2764-2770.

[34] A.S. Wagh, J.P. Singh, R.B. Poeppel, Dependence of ceramic fracture properties on porosity, J. Mater. Sci. 28 (1993) 3589-3593.

[35] I. Yakub, J. Du, W.O. Soboyejo, Mechanical properties, modeling and design of porous clay ceramics, Mater. Sci. Eng. A 558 (2012) 21-29.

[36] P.M. Nigay, T. Cutard, A. Nzihou, The impact of heat treatment on the microstructure of a clay ceramic and its thermal and mechanical properties, Ceram. Int. 43 (2017) 1747-1754.

[37] V.G. Lee, T.H. Yeh, Sintering effects on the development of mechanical properties of fired clay ceramics, Mater. Sci. Eng. A 485 (2008) 5-13.

[38] N. Phonphuak, P. Chindaprasirt, Types of waste, properties, and durability of poreforming waste-based fired masonry bricks, in: F. Pacheco-Torgal, P.B. Lourenço, J.A. Labrincha, P. Chindaprasirt, S. Kumar (Eds.), Eco-efficient Masonry Bricks And Blocks: Design, Properties and Durability, Woodhead Publishing, Cambridge, 2014, pp. 103-127.

[39] L. Aouba, C. Bories, M. Coutand, B. Perrin, H. Lemercier, Properties of fired clay bricks with incorporated biomasses: cases of olive stone flour and wheat straw residues, Constr. Build. Mater. 102 (2016) 7-13. 